\title{
Norske tankesmier i mediene: En suksesshistorie
}

\author{
Paul Bjerke
}

I løpet av 2000-tallet har en ny type aktører etablert seg i det norske politiske systemet. De kaller seg gjerne tankesmier eller tenketanker. Fenomenet vokste fram i USA tidlig i forrige århundre, og deres suksess blir ofte forklart med særtrekk ved det amerikanske politiske systemet, blant annet svake og lite ideologiske partier (Rich, 2005, Abelson, 2009). Men i vår tid har de spredd seg til store deler av verden (Stone \& Denham, 2008). Nå er de også kommet til Norge. En av tankesmienes viktigste målsettinger er synlighet i offentligheten. Denne artikkelen kartlegger derfor omfang og karakter av omtalen av tankesmiene i de sju største norske papiravisene i 2013. Tankesmier er ifølge McGann \& Weaver (2000) «non-governmental, not-for-profit, research organisations with substantial organizational autonomy from government and from societal interest such as firms, interest groups and political parties». Det er en ganske vid definisjon. Hva er det så disse mangslungne organisasjonene har felles - og hva skiller dem fra forskningsinstitusjoner, politiske partier, konsulentselskaper og gravende journalister som også samler, syntetiser og skaper informasjonsprodukter, «often directed towards a political or bureaucratic audience», men "also for the benefit of the media, interest groups, business and the general public» (Stone \& al 1998, 2). For det første må de være «relativt uavhengige» av myndigheter, politiske partier og pressgrupper. Tenketankenes virksomhet må videre ha et klart element av forskning og/eller analyse. Men norske fordi mange tankesmier driver lite egen forskning, det er derfor tilstrekkelig at de «lener seg på forskning» (Johnsen, 2006). Endelig skal tankesmiens virksomhet være innrettet på å påvirke politiske beslutninger og/eller på opinionen. Stone \& al (1998) mener organisasjonene også må ha et ønske om å påvirke politiske beslutningsprosesser for å kunne omtale som tankesmier.

I forskningslitteraturen er think tanks ofte blitt delt i ulike grupper, der de tre hovedformene, etter R. Kent Weaver (Weaver, 1989, McCann \& Weaver, 2000), er:

- «university without students» (universiteter uten studenter) som legger hovedvekten på langsiktig akademisk arbeid og er finansiert av myndigheter, filantropiske fond, selskaper og individer. Deres viktigste output har tradisjonelt vært bøker. 
- «contract research organisations», (oppdragsforskningsinstitutter) som har prosjekter på kort- og mellomlang sikt. De publiserer gjerne rapporter, og de får i all hovedsak sine inntekter fra offentlige og private oppdragsgivere.

- «advocacy think tanks» (opinionsdannende tenketanker) som også arbeider på kort og mellomlang sikt. De har en tydelig ideologisk målsetting og plattform. Slike tankesmier produserer gjerne en mix av bøker, artikler, tidsskrifter og kortrapporter og arrangerer møter/konferanser. Slike opinionsdannende tankesmier er normalt ikke finansiert av myndigheter, men av det sivile samfunn.

\section{Det norske bildet}

Det finnes knapt norsk forskning på tankesmier. Det er skrevet to hovedoppgaver om fenomenet (Johnsen, 2006, Ursin, 2007a) og noen masteroppgaver om Civitas betydning i enkeltsaker (Aanensen, 2006, Jensen, 2010). Jeg har tidligere (Bjerke 2015) kartlagt omfanget av tankesmiene i Norge. Her vil jeg i tillegg peke på et nasjonalt særtrekk: I Norge eksisterer det få eller ingen «universiteter uten studenter». Derimot finnes en stor sektor med samfunnsvitenskapelige forskningsinstitutter som i hovedsak lever av oppdragsforskning, gjerne for ulike offentlige myndigheter. Johnsen (2006) konkluderer at både Forskningsstiftelsen Fafo, ${ }^{6}$ Nova $^{7}$ og Civita $^{8}$ «i mer eller mindre grad matcher» hans definitoriske kriterier. Det betyr i praksis at alle de samfunnsvitenskapelige forskningsinstituttene også vil matche kriteriene. Det samme sier Lars Holger Ursin i en artikkel:

"Instituttsektoren er så omfattende og innflytelsesrik i Norge at den ofte omtales som et særnorsk fenomen - men det er bare delvis riktig. Det er nemlig sterke likhetstrekk mellom den norske instituttsektoren og amerikanske tankesmier, $\mathrm{i}$ alle fall den undertypen som primært driver oppdragsforskning" (Ursin, 2007b).

I en amerikansk rangering over tenketanker (Go To Think Tank) ${ }^{9}$ er Norsk utenrikspolitisk institutt (Nupi) og Peace Research Institute of Oslo (Prio) rangert blant verdens ledende innenfor området internasjonal politikk. Og i en japansk oppstilling $\left(\right.$ NIRA $\left.^{10}\right)$ er Norsk Institutt for oppvekst,

\footnotetext{
${ }^{6}$ Fafo ble startet i 1982 som «Fagbevegelsens senter for forskning, utredning og dokumentasjon» og hadde i starten en svært tydelig karakter av opinionsdannende tankesmie. Senere er Fafo omorganisert til et ordinært oppdragsforskningsinstitutt .

${ }^{7}$ Norsk institutt for forskning oppvekst, velferd og aldring

${ }^{8}$ En liberal tankesmie startet i 2003, se videre nedenfor.

${ }^{9} \mathrm{http}: / /$ gotothinktank.com/

${ }^{10} \mathrm{http}: / /$ www.nira.or.jp/past/ice/ (fra 2005)
} 
velferd og aldring (Nova) registrert som en «think tank». Men i norsk sammenheng er det svært uvanlig å omtale disse instituttene som tenketanker, fordi de ikke har en tydelig ideologisk agenda. I Norge brukes nemlig begrepet «tankesmie» tilnærmet synonymt med «advocacy think tanks». En talende illustrasjon finnes i en artikkel i Ukeavisen Ledelse der professor Frank Aarebrot omtaler Fafo som en tankesmie fordi den er en «premissleverandør» for politikk. Fafo svarer at de ikke er en tankesmie, men en forskningsorganisasjon: «Civita skiller seg fra Fafo ved å være en tankesmie, og har, som tankesmier bør ha, et ideologisk definert utgangspunkt.»» ${ }^{11}$ Gulbrandsen \& al (2013) har kartlagt den norske instituttsektoren. Gjennomgangen viste at det fantes 26 samfunnsvitenskapelige forskningsinstitutter i 2013, med en samlet omsetning på over en milliard kroner. Svært mye av virksomheten er kartlegging, analyse og policyutforming for offentlig sektor. Denne sektorens posisjon og betydning for norsk politikk og politisk kommunikasjon er åpenbart et interessant tema. ${ }^{12}$ Det kan blant annet diskuteres i hvilken grad instituttene er «uavhengige av myndighetene». ${ }^{13}$ Jeg vil her avgrense temaet til de opinionsdannende tenketankenes gjennomslag i mediene. Slike tankesmier har politisk påvirkning og innflytelse som mål og mediesynlighet som en av hovedmetodene i dette arbeidet.

\section{Teoretisk forståelse av opinionsdannende tankesmier}

Den internasjonale litteraturen om «advocacy think tanks» er voksende. Tilnærmingen er ofte tverrfaglig, og det kan etter mitt syn utskilles i alle fall to hovedsynspunkter. En statsvitenskapelig forståelse ser opinionsdannende tankesmier som en forholdsvis «nøytral» eller «tom» organisasjonsform som ulike typer interesser (politiske, økonomiske, sivile osv.) kan bruke til å fremme sine interesser på det politiske «market of ideas» (Barana \& Sciotino, 2011, se også Pautz, 2011, Stone \& Denham, 2008). Denne forståelsen knytter an til pluralistiske teorier eller eliteteorier som begge studerer tankesmier som en del av kampen om politisk innflytelse mellom

\footnotetext{
${ }^{11}$ Ukeavisen Ledelse, 9.8.2013

${ }^{12}$ Et eksempel som illustrerer problemstillingen er evalueringen av sexkjøpsforbudet, som regjeringen satte ut på anbud i 2013. Da lot Fafo være søke og begrunnet det med at rammene for evalueringen var slik at de mente det var faglig uforsvarlig å gjennomføre oppdraget (Aftenposten 10.1.14). I stedet ble evalueringen foretatt av konsulentselskapet Vista Analyse som konkluderte med at loven hadde virket etter hensikten. Konklusjonen fikk stor politisk betydning - og Fafo polemiserte deretter mot funnene i offentligheten.

${ }^{13}$ I den siste norske forskningsmeldingen drøftes dette overhodet ikke. Argumentasjonen i meldingen for ikke å gripe inn med mer politisk styring var at det ikke er nødvendig, ikke at det ikke bør gjøres.
} 
interessegrupper, organisasjoner, partier osv. Det gjøres f.eks. nettverksstudier som legger vekt på at tankesmier arbeider for å påvirke dagsorden utenfor de vanlige kanalene for beslutningstaking ved hjelp av «economy of connections», der kontakter er den harde valutaen (Garsten, 2013, 151).

Opinionsdannende tenketanker er også beskrevet som del av "an institutional field for corporate-political interaction" (Barley, 2010), et nettverk der bevilgende bedrifter, interesseorganisasjoner eller andre bruker tenketanker, ad hoc-grupper, PR-firmaer, konsulenter og advokatfirmaer til å øve innflytelse på sine primærmål, som er regjering og lovgivere. Media er her altså ikke hovedmålet for virksomheten, men et middel (Barley 2010). En skandinavisk variant av denne forståelsen er å legge vekten på at tankesmier vokser fram som et resultat av at samfunnet avkorporativiseres og medialiseres. Da skapes et økende behov for «uavhengig ekspertise» som både kan påvirke opinionen gjennom mediene og beslutningstakere direkte (se også artiklen af BlachØrsten \& Kristensen), og for aktører som ved hjelp av mobilisering, dagsordensetting og overtalelse kan utøve «soft power» (Garsten, 2013:143).

Den andre hovedtilnærmingen er historisk-sosiologisk og ser tankesmier som en spesiell form for organisering som neoliberale interesser med hell har benyttet de siste femti årene og som så med noe mindre hell - blir kopiert av andre grupperinger og interesser (McKewon, 2012, Jaques \& al., 2008, Djelic, 2015). Franske Marie Louise Djelic oppfatter f.eks. de neoliberale tankesmiene som en institusjonalisert oppfinnelse i den hensikt å spre ideer for å forandre verden (Djelic, 2015). I denne prosessen spiller såkalte transnasjonale fellesskap (Djelic \& Quack, 2010, Plehwe, 2010) en helt sentral rolle. Djelic beskriver hvordan aktører som Anhony Fisher, direkte og personlig inspirert av markedsliberalismens ledende teoretiker Friedrich Hayek, systematisk bygde opp markedsliberale tankesmier over hele verden: «When there were only a couple of neoliberal think tanks thirty years ago, today there are close to four hundred in more than 70 nations across the world» (Djelic, 2015). Jeg har andre steder beskrevet (Bjerke, 2015) hvordan den norske liberale tankesmien Civita ble etablert etter påvirkning og mønster fra Fishers Institute of Economic Affairs og svenske Timbro. Denne forståelsen har sine aner i neomarxistiske tradisjoner, særlig en retning som trekker veksler på Antonio Gramscis begreper om hegemoni og organiske intellektuelle (Stone \& Denham, 2008), som er knyttet til «interessepartier» $\mathrm{i}$ vid forstand. Det hevdes at samfunnsvitenskapelig ekspertise $\mathrm{i}$ tenketanker og transnasjonale nettverk "omformer interesser og fordelingskonflikter til ideologiske konflikter" (Rudloff, 2004, sitert i Pautz, 2012). Eller som Plehwe skriver: "Specific and particular interests can attain the status of general interests only if they are well understood, expressed and advocated as well as effectively legitimized" (Plehwe, 2010:306). Fellestrekket i begge 
tilnærmingene er at de ser tankesmier som ledd i kampen om innflytelse og opinion, altså som genuint politiske aktører - selv om de iblant driver nettverksbygging i det skjulte - i stor grad er innrettet på åpen ideologisk strid. De «trivs best i öppna landskap», som den svenske sangeren Ulf Lundell sier. Opinionsdannende tankesmier har følgelig synlighet og medieomtale som et mål. De opinionsdannende tankesmiene er følgelig organisert for opinionsdanning, dels gjennom egne publikasjoner og skoleringstilbud, dels gjennom «agendasetting» (McCombs and Shaw, 1972) og «framing» (Entman, 1993) i mediene. Internasjonale studier viser videre at slike organisasjoner normalt har som hovedstrategi å benytte etablerte og tradisjonelle massemedia i dette arbeidet (Weaver, 1989, Rich \& Weaver, 2000, Feldman, 2007, McKewon, 2012, Clark \& Roodman, 2013, Blach-Ørsten \& Kristensen, 2016). De legger altså normalt mindre vekt på egne publikasjoner, og sosiale medier brukes først og fremst til å spre artikler som er publisert i de tradisjonelle mediene. De ansatte i tenketanker skriver leserinnlegg og kronikker, de konstruerer «pseudobegivenheter» (Boorstin, 1961) av typen pressefrokoster, pressekonferanser og bokutgivelser (ofte på strategiske tidspunkter, med sikte på journalistisk dekning i sentrale nyhetsmedier (McKewon, 2012)). Ansatte i opinionsdannende tenketanker er dessuten ofte populære intervjuobjekter i et bredt utvalg av saker. McKeewon skriver at «the primary role of neoliberal think tanks is to access the media in order to influence public opinion and advocate policies that are consistent with the interests of their organisational sponsors» (McKewon, 2012). Det har ifølge ham, lykkes. Disse tenketankene er nemlig «among the most influential news sources in USA and Australia”. Mens Jaques \& al. (2008) viser at 92 prosent av 151 kartlagte klimaskeptiske bøker er finansiert av konservative tenketanker og at "the successful use of this tactic ("scepticism") has contributed to the weakening of US commitment to environmental protection." (Jaques \& al., 2008, 349). Opinionsdannende tankesmier er derfor styrt av en annen etikk og logikk enn de andre think tanks-typene. Det avspeiles også $i$ rekrutteringspolitikken, der opinionsdannende tenketanker gjerne rekrutterer ansatte på et (allmenn)politisk grunnlag: «A staff of academics is almost certainly inapropriate for an 'advocacy think tank", skriver Weaver (1989). Kvalitative intervjuer med tankesmiene i Bjerke (2015) bekrefter at norske tankesmier også har mediesynlighet som et viktig mål i sitt arbeid. Har de lykkes?

\section{Metodiske merknader}

For å besvare dette forskningsspørsmålet har jeg gjennomført en studie av i hvor stor grad og på hvilken måte ledende norske papiraviser omtaler tankesmier. I tråd med Weaver (1989) har jeg først operasjonalisert «opinionsdannende tankesmie» som uavhengig, forskningsbasert, policyorientert og 
ikke-kommersiell kommersielle organisasjoner og med et åpent ideologisk og/eller politisk ståsted som den ønsker å fremme.

Kartleggingen av tankesmier er deretter foretatt på basis av søk på begrepene «tankesmie»og «tenketank» i søkemotoren Google. Jeg forutsatte at denne typen tankesmier har en viss synlighet på Internett. ${ }^{14}$ Gjennom søket ble det funnet en rekke mulige organisasjoner, som så ble gjenstand for en nærmere analyse for å se om disse kriteriene ble oppfylt. ${ }^{15}$ Det var ingen av de aktuelle tankesmier som ble fravalgt i denne prosessen. To av dem er diskutable. Mandag Morgen var en blanding av nett-publikasjon med faste utgivelser og tankesmie; mens Kristendemokratisk Forum er svært tett knyttet til Kristelig Folkeparti. Men begge har såpass tydelige trekk av tankesmier at jeg valgte å ta dem med. Resultatet av kartleggingen er gjengitt i Tabell 1.

Som det framgår av tabellen, har jeg funnet 13 organisasjoner som oppfyller mine kriterier for å bli kategorisert som («opinionsdannende tankesmier») og som var aktive i 2013. Heretter i kapitlet blir de omtalt bare som «tankesmier» eller «tenketanker». Alle er små organisasjoner. Den største, Civita, hadde i 2013 ni årsverk og et budsjett for året på rundt 12 millioner kroner. Agenda, som ble operativ våren 2014, har i dag en liknende størrelse. Manifest og Res Publica har 4-5 ansatte, mens Human Rights Service, Skaperkraft og Minotenk i praksis er 1-2 mannsbedrifter. Alle disse tankesmiene har, men i varierende grad, prosjektmedarbeidere, stipendiater, studenter og forfattere tilknyttet virksomheten. De øvrige tankesmiene på lista sysselsetter mindre enn ett årsverk. I alt engasjerte norske tankesmier i 2013 bare rundt 20 årsverk. Det har i dag steget til rundt 30 årsverk og en samlet årsomsetning på 30-40 millioner. Sammenliknet med sysselsettingen i liknende felt som samfunnsvitenskapelig oppdragsforskning, journalistikk, politiske partier og informasjon/PR, er omfanget bagatellmessig.

\footnotetext{
${ }^{14}$ En mulig feilkilde er at organisasjoner som ikke kaller seg «tankesmier» eller «tenketanker», men likevel oppfyller kriteriene, på denne måten faller utenfor kartleggingen. Men når oppdragsforskningsinstituttene i utgangspunktet er definert ut, er dette neppe noe problem. Jeg har presentert funnene i flere relevante sammenhenger og ingen har etterlyst noen organisasjoner som burde vært tatt med, men ikke er det.

${ }^{15}$ Jeg har også gått gjennom noen av de aktuelle NACE-kodene (statistiske næringskoder) på nettstedet proff.no, men det viser seg at de fem mest kjente tankesmiene har registrert seg på fem ulike koder, slik at gjennomgangen var lite nyttig for mitt formål. I NACE-registret finnes det en rekke enkeltmannsforetak som etter en slik definisjon kunne vært registrert som tankesmier, men slike er holdt utenfor kartleggingen.
} 
Tabell 1 Norske tankesmier i 2013

\begin{tabular}{|l|l|l|}
\hline Navn & Ansatte & Ideologisk grunnlag (tredelt) \\
\hline Civita & 9 & Høyre \\
\hline Agenda & $-{ }^{16}$ & Venstre \\
\hline Manifest analyse & 4 & Venstre \\
\hline Human Rights Services & 2 & Høyre \\
\hline Res Publica & 5 & Venstre \\
\hline Minotenk & 3 & Sentrum \\
\hline Skaperkraft & 2 & Sentrum \\
\hline Kristendemokratisk forum & - & Sentrum \\
\hline Sosialliberalt verksted & - & Sentrum \\
\hline Kristen og Progressiv & - & Venstre \\
\hline Føniks - ruspolitisk tenketank & - & Sentrum \\
\hline Ludwig von Mises-instituttet i Norge & - & Høyre \\
\hline Mandag Morgen ${ }^{17}$ & - & Høyre \\
\hline
\end{tabular}

\section{Pressedekning av tankesmier}

Jeg har deretter tallfestet den offentlige interessen for tankesmier gjennom å studere pressedekningen, definert som omtale i landets sju største papiraviser, basert på opplagstall fra Mediebedriftenes Landsforbund:

Tabell 2. Aviser i studien. Faglig og ideologisk profil. Opplag 2013

\begin{tabular}{|l|l|l|l|}
\hline Aftenposten & Broadsheet & Høyre & $\mathbf{2 1 6 0 0 0}$ \\
\hline Dagens Næringsliv & Business & Høyre & 80000 \\
\hline Dagbladet & Tabloid & Sentrum & 80000 \\
\hline VG & Tabloid & Høyre & 164000 \\
\hline Stavanger Aftenblad & Regional & Sentrum & 59000 \\
\hline Adresseavisen & Regional (Trondheim) & Høyre & 67000 \\
\hline Bergens Tidende & Regional & Høyre & 73000 \\
\hline
\end{tabular}

\footnotetext{
${ }^{16}$ Etablert i løpet av 2013. Vokst til ca. ti ansatte i 2014.

${ }^{17}$ Mandag Morgen ble nedlagt i løpet av 2013.
} 
Papiraviser er valgt fordi det fortsatt er disse som i stor grad setter dagsorden for den politiske debatten. Studier, både i Norge (Erdal, 2010) og internasjonalt (Pew Research Center, 2011, Lund \& al, $2009^{18}$ ), viser at det er de «gamle» avisredaksjonene som produserer nesten alle nyheter, og det er avisenes kronikk- og debattsider som ofte er utgangspunkt for etermedienes debattprogrammer. Innsamlingen av relevante artikler ble gjort ved hjelp av søkemotoren på avisdatabasen Retriever. Søkeord var navnet på tankesmien. Samtlige artikler der en tenketanks navn var nevnt, er tatt med i analysen. Tabell 3 viser den samlede omtale av tankesmier i de sju avisene i 2013

Tabell 3 Antall artikler i de sju største avisene der en tankesmie er nevnt. Etter tankesmie. Antall ${ }^{19}$

\begin{tabular}{|l|l|}
\hline Tankesmie & $\mathbf{2 0 1 3}$ \\
\hline Civita & 369 \\
\hline Manifest & 52 \\
\hline Agenda & 48 \\
\hline Human Rights service & 33 \\
\hline Res Publica & 21 \\
\hline Progressiv & 15 \\
\hline Skaperkraft & 13 \\
\hline Minotenk & 11 \\
\hline Mandag morgen & 3 \\
\hline Totalsum & $\mathbf{5 6 5}$ \\
\hline
\end{tabular}

Tabellen viser at de sju avisene i 2013 totalt hadde 565 artikler der tankesmiene på noe vis var omtalt. Den (markeds)liberale tenketanken Civita var suverent mest omtalt, ${ }^{20}$ klart mer enn alle de andre tankesmiene til sammen. Om dette totalt sett er mye eller lite omtale, er naturligvis et skjønnsspørsmål. Men en opptelling på Retreiver av omtalen av tankesmier og noen andre politiske aktører og forskningsinstitusjoner i 2013 viser følgende:

\footnotetext{
${ }^{18}$ Den danske nyhetsundersøkelsen er gjentatt i 2012 og foreløpige, ikke-publiserte resultater viser at mønstret fortsatt er det samme.

${ }^{19}$ I samband med en fellesnordisk studie ble det også gjort en opptelling på samme måte i 2006. Resultatet var 200 artikler. Det betyr en klar økning fra 2006 til 2013. Det har to årsaker, dels er det blitt flere tankesmier, dels er de tankesmiene som eksisterte både i 2006 og i 2013 i hovedsak omtalt i større omfang.

${ }^{20}$ Civita var også klart mest omtalt i 2006.
} 
Tabell 4. Antall artikler i Norges sju største aviser som inneholder omtale av henholdsvis tankesmier Nupi, ISF, Fagforbundet, Fellesforbundet og Universitetet i Oslo. 2013

\begin{tabular}{|l|l|}
\hline Emne & Omtale \\
\hline Tankesmier & 565 \\
\hline NUPI (Norsk utenrikspolitisk institutt) & 201 \\
\hline ISF (Institutt for samfunnsforskning) & 145 \\
\hline Fagforbundet (Kommuneansatte) & 443 \\
\hline Fellesforbundet (Industriansatte) & 164 \\
\hline Universitetet i Oslo & 1800 \\
\hline
\end{tabular}

Tabell 4 viser at tankesmiene er vesentlig mer omtalt enn mer etablerte og langt større «contract research organisations» som Nupi (Norsk utenrikspolitisk institutt), og Institutt for samfunnsforskning. Nupi har 60 ansatte. ISF 56. De ganske små tenketankene er omtalt like mye som Norges to største fagforbund, Fagforbundet og Fellesforbundet, til sammen. De to fagforbundene har totalt rundt en halv million medlemmer. Det er også interessant at Norges største universitet, Universitet i Oslo, bare er omtalt tre ganger så ofte som de små tankesmiene.

\section{Veier til mediedekning}

De norske tenketankene forsøker å skaffe seg innflytelse gjennom tre hovedstrategier: Utgivelse av bøker/rapporter, direkte mediekontakt og nettverksbygging. Mediesynlighet bygger de både med bokutgivelsene og den direkte kontakten (Bjerke 2015). Tankesmiene utgir både dagsaktuelle, politiske og mer allmenngyldige, faglige bøker. Bokutgivelsene er nært knyttet til tankesmiens formål. I 2013 utga f.eks. den sosialdemokratiske Res Publica boka Blåkopi av Wegard Harsvik (Harsvik, 2013). Den var direkte innrettet på å støtte Arbeiderpartiet og deres allierte i den norske valgkampen. Middelet var en kritisk gjennomgang av det svenske høyrepartiets politikk og det norske Høyres angivelige kopi av denne. Den andre boka var derimot en utfordring også til de rødgrønne, en ny norsk oversettelse av Torstein Veblens sosiologiske klassiker The Leisure Class (Den uproduktive klassen) (Veblen, 2013). Utgivelsene får ofte omtale i dagspressen og i etermedienes 
aktualitetsendinger og debattprogrammer. Avisomtalene legges normalt ut som linker på tankesmienes egen hjemmeside. I løpet av den første måneden hadde f.eks. Res Publica lagt ut 20 slike lenker om Blåkopi. Civita utga i 2013 seks bøker, alle med en klar liberal profil: Mest direkte innrettet på den aktuelle politiske situasjonen i Norge var Mathilde Fasting Valgfrihet (Fasting, 2013a) og en utgivelse om den første borgerlige samlingsregjeringen i Norge etter annen verdenskrig. Begge bøkene ble presentert som faglige utgivelser (en idehistorisk og en historisk). Men de ble (også) oppfattet som innspill i den aktuelle politiske debatten før stortingsvalget i 2013.

Tankesmiene produserer også kortrapporter. I 2013 hadde Civita mediesuksess med Fastings notat om Arbeidstidsreglene i offentlig sektor (Fasting, 2013b). Res Publica utga boligforskeren Arild Holt-Jensens rapport om norsk boligpolitikk (Holt-Jensen 2013), mens Manifest fikk en viss medieomtale rundt sin rapport om OPS (Offentlig-privat samarbeid) i helsesektoren (Pollock, 2013). Fellestrekket i disse rapportene er at de samler og syntetiserer kunnskap på et aktuelt felt, både fra forskning og fra konsulentrapporter og medieoppslag. Rapportenes innhold formidles gjennom journalistiske medier på to måter, som iblant kombineres. Dels skriver forfatterne kronikker med sine hovedfunn/påstander, dels tilbyr de innholdet (gjerne eksklusivt) til en redaksjon som da kan lage et nyhetsoppslag, basert på innholdet i rapporten. Poenget er at medieoppslaget helst ikke skal handle om rapporten, men om innholdet i den. Da Manifest laget en rapport om offentlig-privat samarbeid (OPS), var det VG som ble tilbudt saken, og som laget et oppslag ${ }^{21}$ om OPS med følgende ingress: «Investorene jubler over Høyres veipolitikk: Lav risiko og god avkastning kan skape et nytt marked for pengeplassering». Dermed fikk Manifest sitt politiske poeng fram gjennom en nyhetsartikkel i den største og mest innflytelsesrike av de norske tabloidavisene. Noe av det samme oppnådde Civita da Mathilde Fasting framsto som ekspertkilde i en større nyhetsartikkel knyttet til oppstarten av forhandlingene mellom KS og lærerne om arbeidstid høsten $2013 .^{22}$ Fasting hadde da nettopp ferdigstilt rapporten om teamet og ble benyttet av businessavisa Dagens Næringsliv til å analysere forhandlingene.

\section{Synlighet i avisartikler}

Den andre måten å skaffe seg mediesynlighet på er ved å produsere debattinnlegg og kronikker. Tankesmiene oppfatter at det er forholdsvis enkelt å komme på trykk (Bjerke 2015). Dataene fra

\footnotetext{
${ }^{21} \mathrm{VG}, 28.7 .2013$, s . 15.

${ }^{22}$ Dagens Næringsliv 18.11.2013, s. 6.
} 
denne innholdsanalysen peker i samme retning. 18 prosent av avisartiklene der en tankesmie er nevnt, er kronikker eller debattinnlegg fra tankesmiene selv. Det går fram av Tabell 5:

Tabell 5 Fordeling av artikler etter sjanger og forfatter

\begin{tabular}{|l|l|l|}
\hline Sjanger & Antall & Prosent \\
\hline Nyhet & $\mathbf{1 5 6}$ & $\mathbf{2 8}$ \\
\hline Kommentar & $\mathbf{1 1 9}$ & $\mathbf{2 1}$ \\
\hline Kronikk & & \\
\hline Tankesmie & 101 & 18 \\
\hline \multicolumn{1}{|c|}{ Andre } & 105 & 19 \\
\hline Notiser & 84 & 15 \\
\hline Totalsum & $\mathbf{5 6 5}$ & $\mathbf{1 0 1}$ \\
\hline
\end{tabular}

Vi ser at 101 artikler (18 prosent) av alle artiklene der tankesmier er nevnt, er debatt- og kronikkinnlegg som er skrevet av deres egne representanter. Gjennom slike kronikker og leserinnlegg kan man lansere rapporter, debatter, ideer - og nye tolkninger og innramminger av aktuelle problemstillinger. Tallene viser tydelig at tankesmiene lykkes $\mathrm{i}$ å skape debatt om sine forslag. Redaksjonene (og andre innsendere) tar opp, roser og kritiserer innspillene. Det blir gjort på et bredt spekter av områder. Det går fram av tabellen under:

Tabell 6. Artikler der tankesmier er nevnt. Etter hovedtema.

\begin{tabular}{|l|l|}
\hline Tema & $\mathbf{2 0 1 3}$ \\
\hline Ideologi & 87 \\
\hline Tankesmien selv & 67 \\
\hline Kultur og media & 50 \\
\hline Velferd og helse & 39 \\
\hline Økonomi & 36 \\
\hline Innvandring & 31 \\
\hline Arbeid & 30 \\
\hline Utenriks & 27 \\
\hline Utdanning & 25 \\
\hline Skatt & 22 \\
\hline Privatisering & 15 \\
\hline Menneskerettigheter & 13 \\
\hline Annet & 123 \\
\hline Sum & 565 \\
\hline
\end{tabular}


Vi ser at tankesmiene opptrer i artikler med et svært bredt spekter av tema; fra ideologi og historie via skole, medier og samferdsel til skatt og makroøkonomi.

Hvordan blir så tankesmiene presentert i avisene? Blir deres utspill og/eller organisasjonen selv framstilt positivt eller negativt. I tabellen under er det brukt en grov inndeling av tankesmier $i$ høyre/venstre-orientert (jf. Tabell $1^{23}$ ) og en inndeling $\mathrm{i}$ «tendens» $\mathrm{i}$ omtalen, der «positiv» betyr at tankesmien er framstilt i et positivt lys og/eller tankesmiens utspill er positivt vurdert, mens «negativ» innebærer negativ vurdering eller omtale. «Nøytral» betyr at artikkelen ikke har noen tydelig tendens.

Tabell 7. Tendens $\mathrm{i}$ omtalen av tankesmier i leder/kommentar etter tankesmienes og avisens ideologiske plassering. Prosent. $(N=119)^{24}$

\begin{tabular}{|l|l|l|l|l|}
\hline Avis & \multicolumn{2}{|l|}{ Sentrum } & \multicolumn{2}{l|}{ Høyre } \\
\hline Tankesmie & Venstre & Høyre & Venstre & Høyre \\
\hline Positiv & 83 & 28 & 45 & 58 \\
\hline Negativ & 0 & 36 & 36 & 25 \\
\hline Nøytral & 17 & 36 & 18 & 17 \\
\hline Sum & 100 & 100 & 99 & 100 \\
\hline $\mathrm{N}=$ & 13 & 28 & 23 & 55 \\
\hline
\end{tabular}

Som vi ser av tabellen, er et klart flertall av kommentarene i begge tuper aviser positive eller nøytrale til begge kategorier tankesmier. Men vi ser også en tydelig effekt av avisas grunnsyn: Sentrumsorienterte aviser er klart mer positive til venstreorienterte tankesmier og mer negative til de høyreorienterte enn høyreorienterte aviser er. Den velvillige holdningen vises også i hvordan tankesmiene blir presentert i nyhetssakene. Blir de omtalt som partskilder eller som nøytrale «eksperter»:

\footnotetext{
${ }^{23}$ Sentrums-tankesmiene i tabell 1 er her fordelt slik: Minotenk er «venstre», mens Skaperkraft er «høyre». De andre sentrums-tankene er ikke representert i denne tabellen.

${ }^{24}$ Merk at $\mathrm{N}$ er lav i denne tabellen, særlig for sentrumsorienterte aviser. Jeg har derfor gjort samme beregning med materialet fra 2006, og det viser samme tendens.
} 
Tabell 8. Tankesmiens kilderolle i nyhetssakene. $(\mathrm{N}=156)$

\begin{tabular}{|l|l|}
\hline Kilderolle & Totalsum \\
\hline Ekspert & 54 \\
\hline Partskilde & 27 \\
\hline Annet & 19 \\
\hline Totalsum & $\mathbf{1 0 0}$ \\
\hline $\mathbf{N}=$ & $\mathbf{1 5 6}$ \\
\hline
\end{tabular}

Tabellen viser at $\mathrm{i}$ et flertall av nyhetssakene der tankesmiene opptrer som synlige kilder, har de karakter av «nøytrale eksperter», ikke partskilde. Det betyr at tenketankene er presentert uten en ordmarkør som f.eks. «liberal» eller «venstreorientert». Dette gjelder for de fleste tankesmiene. ${ }^{25}$ Tankesmienes målgruppe er ikke først og fremst «befolkningen». Det er heller ikke den sittende regjering. Tankesmienes virksomhet handler mye om å påvirke tenkningen til ledende intellektuelle sjikt - på lengre sikt (Djelic, 2015, Bjerke, 2015). Dette kan illustreres av hvor de velger å publisere og hvilke typer aviser som er interesserte i deres utspill og innspill:

Tabell 8. Omtale av tankesmier i avisene. Etter avistittel. Prosent

\begin{tabular}{|l|r|}
\hline Aviser & $\mathbf{2 0 1 3}$ \\
\hline & 3 \\
\hline Adresseavisen (Trondheim) & 25 \\
\hline Aftenposten (Oslo) & 19 \\
\hline Bergens Tidende & 19 \\
\hline Dagbladet (Oslo) & 16 \\
\hline Dagens Naringsliv (Oslo) & 8 \\
\hline Stavanger Aftenblad & 10 \\
\hline VG & \\
\hline & $\mathbf{1 0 0}$ \\
\hline Totalsum & 565 \\
\hline N=
\end{tabular}

Av tabellen ser vi at tankesmiene er mest omtalt i Osloavisene, særlig lav er interessen i Stavanger og Trondheim. Populæravisen VG skriver også mindre om tankesmiene enn Aftenposten og

\footnotetext{
${ }^{25}$ Men for mange av de mindre tankesmiene er det her snakk om svært små tall.
} 
næringslivsorganet DN. Denne fordelingen gjelder også tekster som tankesmiene skriver selv. 44 av Civitas 78 innlegg og kronikker i 2013 har vært på trykk i Aftenposten og DN, bare fem i VG. Spissformulert kan man si at tankesmiene prioriterer og blir prioritert av Osloaviser med høystatus lesergrupper. ${ }^{26}$

\section{Diskusjon}

Vi ser altså at tankesmiene omtales bredt og positivt, og vi ser at den liberale Civita blir klart mest (og i all hovedsak positivt) omtalt. Det står i sterk motsetning til det som skjedde med den liberale tankesmiens forløper. Civita ble nemlig dannet av LiFo, restene av organisasjonen Libertas som ble stiftet rett etter annen verdenskrig og som i hovedsak skulle samle inn penger til de borgerlige partiene. Men den hadde forsøkt å etablere seg i hemmelighet, noe som viste seg ødeleggende da det ble kjent (Riksaasen, 1973). Etter at dette ble avslørt i Arbeiderbladet i 1947, ble Libertas finansiert av redernes og næringslivets organisasjoner og konsentrerte seg i stedet om ideologisk arbeid, blant annet produksjon og utgivelse av bøker og pamfletter og kursvirksomhet på Elingaard gods i Østfold. Libertas tilfredsstiller de aller fleste kjennetegn på en opinionsdannende tankesmie, men dette begrepet ble aldri brukt om den. Organisasjonens formål var erklært liberalt: «arbeide for næringsfrihet, åndsfrihet og politisk frihet som grunnlag for en fullverdig livsstandard for alle». Libertas ble - i motsetning til Civita - aldri «stuerene» i norsk politikk. Spørsmålet er derfor hvorfor situasjonen er en helt annen i dag.

En viktig årsak er naturligvis endringer i det ideologiske klimaet: Markedsliberalismen var en marginalisert politisk-økonomisk retning fra 1945 fram til de økonomiske krisene i Vesten på 1970tallet. Libertas kunne (med hell) avvises som en «reaksjonær» «propagandasentral» av Arbeiderpartiets ideologer (Brunvand, 1960). Da Civita ble etablert, med de samme økonomiske bidragsytere og det samme politiske programmet rundt årtusenskiftet, var denne typen argumentasjon virkningsløs og ble bare benyttet av ytre venstre-krefter. Den senere lederen for Manifest, Magnus Marsdal, skrev i 2004 at «Er det ikke relativt åpenbart hvilke konklusjoner en tankesmie for samfunnets rike og mektige vil komme fram til?». ${ }^{27}$ (Marsdal, 2004).

Men, som vi ser av tabell 8; Civitas, Manifests og de andres ideologiske plassering blir i de fleste tilfeller ikke gjort kjent for leserne. Tankesmiens representanter presenteres heller som

\footnotetext{
${ }^{26}$ Dette illustreres også av at et søk på Civita i Morgenbladet, en ukeavis innrettet på høyt utdannede, gir hele 40 treff i 2013.

${ }^{27}$ Klassekampen 23.4.2004.
} 
«nøytrale eksperter». Ettersom dekningen ellers i all hovedsak er positiv eller nøytral og 34 prosent av nyhetsartikler og notiser har utgangspunkt i innspill, utspill eller pseudobegivenheter fra tankesmien selv, tyder funnene på at tankesmiene - helt uavhengig av ideologisk plassering - lykkes i å skape positiv oppmerksomhet i mediene rundt sine utspill. Dette peker i retning av også andre årsaker enn politisk klimaskifte for å forstå tankesmienes gjennomslag i vår tid. Tankesmier har lenge vært knyttet til USA. Og noe av forklaringen har vært at det amerikanske partisystemet mer er kampanjeorganisasjoner for personer enn politiske «verksteder». Når de norske partiene er blitt svekket som arenaer for poltikkutvikling gjennom de siste 25 årene, når tallet på partimedlemmer er raskt synkende og når det dessuten blir stadig færre folkevalgte, oppstår et behov for andre organisasjoner som kan «tenke langsiktig».

Et tilliggende moment er at USAs partipressesystem ble avviklet på 1800-tallet. USA hadde altså ingen partipresse da tankesmiene vokste fram i det tjuende århundret. En mulig medvirkende årsak til at tankesmier kom sent i Norge, er derfor partipressens fall. Mediehistoriker Henrik Bastiansen skriver:

”Det DNA-dominerte statsapparatet som ble bygd ut i Einar Gerhardsens regjeringstid var i stor utstrekning basert på at arbeiderpressen drev systematisk meningsdanning for å sikre den nødvendige velgeroppslutning som skulle til” (Bastiansen, 2009:41).

Sentrum i denne meningsdanningen på venstresiden var Arbeidernes Pressekontor i Oslo, som allerede i 1949 hadde mer enn ti ansatte og som ved siden av ordinær nyhetsformidling hadde som formål «å sørge for den best mulige politiske orientering gjennom fortrolige informasjoner og politiske artikler» (Bastiansen, 2009, 41). Partipressesystemet sto under partikontroll og var slik sett ikke tankesmier i dagens forstand, men det kan neppe være tvil om at det foregikk omfattende politikkutvikling i disse organisasjonene og i nettverket mellom avisenes redaktører og politiske journalister. Bastiansen peker f.eks. på at Senterpressen, som i motsetning til AP knapt hadde sentralt ansatte, var navet i en «sirkulasjon av meninger mellom Senterpartiet, Senterpartiets pressekontor og Senterpressen som rent ideologisk skilte seg nokså sterkt fra både A-pressen. Høyrepressen og Venstrepressen. Det var organisasjoner som talte «bygdefolkets sak». Slik ble Senterpressen et bygdepolitisk oppdemmingssystem, en agrar motkraft» (Bastiansen, 2009). I løpet av 1990-tallet ble partipressen erstattet av konserndannelser, der redaktørene ble bedriftsledere (Roppen, 1996), og der (parti)politisk uavhengighet ble en dyd for alle journalister. Mange har hevdet partipressen var servil. Det er bare halvveis riktig. Avisene var lojale (og servile) mot sine partier. Men de var skarpt kritiske 
mot de konkurrerende partiene. De sørget derfor for omfattende politisk debatt og politikkutvikling i offentligheten. De mer markedstilpassede og politisk forsiktige konsernstyrte avisene påtok seg ikke en slik oppgave. Dermed oppsto det på den ene siden et rom for opinionsdannende tankesmier, og Civita kunne starte opp.

På den andre siden fikk den fristilte pressa (som måtte tone ned sine politiske standpunkter) et behov for «profesjonalisert» kommentar og debattstoff, et behov som nå skjerpes av nedgangen $\mathrm{i}$ partipressas inntekter. Noe av forklaringen på tankesmienes suksess ligger dermed i de samme forholdene som forklarer PR-bransjens innpass i mediene (Allern, 1997, Cappelen, 2013): Det er et resultat av at tankesmiene og media har en felles interesse i denne typen publisering. Tankesmiene er opprettet for å påvirke opinionen, mens media har behov for spissede forskningsresultater, utspill, ideer og tanker som har nyhetsverdi og kan skape konflikt og debatt.

\section{Konklusjon}

Undersøkelsen har vist at norske tankesmier har hatt betydelig gjennomslag i de sju største norske papiravisene og at dekningen $\mathrm{i}$ all hovedsak er velvillig og positiv. Artikkelen har lansert to forklaringer på dette: en er knyttet til endringer i det politiske klimaet, den andre er knyttet til avviklingen av partipressesystemet. Den første forklaringen på de norske tankesmienes mediesuksess trekker på innsikter fra den historisk-sosiologiske analysen av tankesmienes framvekst som tett sammenvevd med den markedsliberale ideologiens suksess. Den andre forklaringen gir mer støtte til den statsvitenskapelige analysen av tankesmiers mediesuksess: de fyller et behov $\mathrm{i}$ et avkorporativisert og medialisert samfunn.

\section{Litteratur}

Barani, L, Sciortino, G (2011), The Role of Think Tanks in The Articulation of The European Public Sphere. Eurosphere Comparative Studies, http://eurospheres.org/files/2010/06/WP 51 final.pdf, lastet ned 10.1.16

Barley, S.R. (2010). Building an Institutional Field to Corral a Government: A Case to Set an Agenda for Organization Studies. Organization Studies 31; 777-805.

Bastiansen, H. (2009) Lojaliteten som brast. Oslo: Pressehistoriske skrifter

Bjerke, P. (2015) 'Tankesmier på norsk - hjemmelaget import' i Allern, S. \& al: Makt, medier, politikk. Oslo: Universitetsforlaget

Boorstin, D.J. (1961). The image: A guide to pseudo-events in America. New York: Vintage

Brunvand, O. (1960) Libertas - en utfordring. Oslo: Det norske Arbeiderparti 
Clark, J. and Roodman, D. (2013) Measuring Think Tank Performace. GCD Policy Paper. Washington_Center for Global Development

Djelic, M.L. (2015). Spreading ideas to change the world: Inventing and institutionalizing the neoliberal think tank. I C. Garsten \& A. Sörbom (red.), Political affair. Bridging markets and politics. Cheltenham, England: Edward Elgar.

Djelic, M.L. \& Quack, S. (2010). Transnational communities. Shaping global economic governance. Cambridge, England: Cambridge University Press.

Entman, R (1993) 'Framing: Toward Clarification of a Fractured Paradigm', Journal of Communication 43 (4): 51-58

Erdal, I. J. (2010) Hvor kommer nyhetene fra. I NOU 2010:14, Oslo: Kulturdepartementet

Fasting, M. (2013a). Valgfrihet. Oslo: Civita.

Fasting, M. (2013b). Arbeidstidsavtaler i offentlig sektor. Oslo: Civita.

Feldman, B. (2007) Report from the field. Left Media and Left Think Tanks. Critical Sociology, 33:427-446

Gandy, O.T. (1982) Beyond agenda setting: Information subsidies and public policy Norwood: Ablex Pub

Garsten, C. (2013). All about ties. Think tanks and the economy of connections. I C. Garsten \& A. Nyqvist (red.), Organisational anthropology. Doing ethnography in and among complex organizations (s. 139-154). London: Pluto Press.

Gulbrandsen, T. \& al (2012) Instituttsektorens rolle og organisering i Norge med spesiell vekt på samarbeid, arbeidsdeling og konsentrasjon. NIFU-rapport 50/2012. Oslo: NIFU

Harsvik, V. (2013) Blåkopi. Høyres svenske strategi for et annerledes samfunn. Siggerud: Res Publica.

Holt-Jensen, A. (2013) Bolig for alle. Rapport. Oslo: Res Publica

Jacques P.J., Dunlap, R.E. \& Freeman, M. (2008). The organization of denial: Conservative think tanks and environmental skepticism. Environmental Politics, 17(3), 349-385

Jensen, A.R. (2010) Basil Bernsteins teori om pedagogiske identiteter brukt i skolepolitisk tekstanalyse. Masteroppgave. Kr.sand; Universitetet i Agder

Johnsen, J. (2006). Norske tenketanker. Definisjonsproblematikk og innflytelsesmuligheter. Masteroppgave. Oslo: Institutt for statsvitenskap, Universitetet i Oslo (UiO).

Liao, X. (2006) Chinese foreign policy think tanks and China's policy towards Japan Hong Kong: Chinese University Press

Lund, A.B., Willig, I. \& Blach-Ørsten, M. (red.) (2009). Hvor kommer nyhederne fra? Den journalistiske fødekcede i Danmark før og nu. Århus: Ajour Forlag.

McCombs, M; Shaw, D (1972). "The agenda-setting function of mass media". Public Opinion Quarterly $36(2)$ 
McGann, J.B., Weaver, R.K. (eds) (2000) Think tanks \& civil societies : catalysts for ideas and action. New Brunswick, N.J. : Transaction Publ.

McKewon, E (2012) 'Talking Poinys ammo. The use of neoliberal think tank fantasy themes to delegetimise scientific knowledge of climate change in Austrialian Newspapers. Journalism studies Vol 13/2: 277-297

Pautz, H. (2011) 'Revisiting the think tank phenomenon', Public Policy and Administration, 26: 419-435

Pautz, H (2012) Think-tanks, social democracy and social policy. Basingstoke: Palgrave Macmillan

Plehwe, D. (2010). The making of a comprehensive transnational discourse community. I M.-L.

Djelic \& S. Quack (red.), Transnational Communities: Shaping global economic governance (s. 305-326). Cambridge, England: Cambridge University Press.

Pollock, A. (2013) OPS i helsevesenet - Storbritannias erfaringer, loerdommer for Norge. Oslo: Manifest

Rich, A and Weaver, R.K (2000). Think tanks in the US Media. Press/Politics 5(4):81-103

Rich, A. (2005) Think Tanks, Public Policy, and the Politics of Expertise Cambridge: Cambridge University Press

Riksaasen, S. (1973). Libertas - bakgrunn, etablering og de første virkeår Hovedoppgave. Oslo: Elingaard.

Roppen, J. (2003) Orklas lange revolusjon. Doktoravhandling. Bergen: Universitetet i Bergen

Stone, D. \& al (1998) Think tanks across nations. Manchester: Manchester University Press

Stone, D., Denham, A. (eds) (2008) Think tank traditions : policy research and the politics of ideas Manchester. Manchester University Press

Ursin (2007b, 01.09) Tankesmier med statsmonopol Bergens Tidende, kronikk, s.12

Ursin (2007a) Tankemeklerne - norske og amerikanske tankesmier i et komparativt perspektiv» Hovedoppgave i sammenliknende politikk. Bergen:UiB

Veblen,T (2013). Den uproduktive klassen ( The leisure Class) Oslo: Res Publica

Weaver, R. Kent (1989) The Changing world of Think Tanks. Political Science and Politics September 1989: 563-578

Aanensen, K. (2006) En tanke tomt - en kvalitativ analyse av tenketanken Civita. Masteroppgave i medievitenskap. Oslo: $\mathrm{UiO}$ 